\title{
UGC's responses to the pandemic: roles of Institutional Quality Assurance Cells in Bangladesh
}

\author{
Jude William Ramiro Genilo \\ Media Studies and Journalism, University of Liberal Arts Bangladesh, \\ Dhaka, Bangladesh
}

\begin{abstract}
Purpose - The paper documents the roles played by the institutional quality assurance cells (IQACs) to implement the University Grants Commission (UGC) directive to shift to online education during the COVID-19 pandemic period in Bangladesh. It highlights the government's efforts to ensure quality education, particularly in utilizing IQACs in the various public and private universities. The paper starts with the pandemic situation in the country, followed by the overall responses of the government, including its directives regarding the conduct of higher education.

Design/methodology/approach - The paper utilizes as framework the Sloan Consortium's Five Pillars of Quality Online Learning - learning effectiveness, student satisfaction, teacher satisfaction, scale and access. The paper then analyzes the oral reports of 26 IQACs, which were presented to government officials in two meetings.

Findings - From the analysis, it is apparent that IQACs have contributed toward the shift to full online education during the pandemic period. Universities responded to the crisis mainly in the areas of governance, teaching and learning and student support services. To guide policy formulation, the IQACs (with the help of other university units) conducted surveys among their faculty and students regarding their access to Internet, financial difficulties and mental health situation. From here, they drafted academic policies (attendance, student assessment and online teaching), conducted capacity building activities, monitored faculty performance, formulated guidelines on student online behavior and encouraged stakeholders to trust the online system.

Originality/value - The study is original since (like many countries) the pandemic has forced education activities to go online. It looks at both the macro level (the concerns of the University Grants Commission or UGC concerning quality education in an online setting) and the micro level (what universities have undertaken to address the concerns of the UGC).
\end{abstract}

Keywords Online learning, Quality education, Bangladesh, COVID-19 response, Pandemic, Quality assurance, IQAC, Higher education, Teaching and learning, University Grants Commission, Online learning platforms, Bangladeshi universities

Paper type Research paper

\section{Introduction}

The paper documented the roles institutional quality assurance cells (IQACs) played to fulfill the University Grants Commission (UGC) directive regarding the shift toward online education during the COVID-19 pandemic period. In so doing, it highlighted the Bangladeshi government's efforts to ensure quality education, particularly in utilizing IQACs in the various public and private universities. The paper started with the pandemic situation in the country, followed by the overall response of the government vis-à-vis the conduct of higher education. With the mandated shift to full online learning, the paper discussed the efforts of

(C) Jude William Ramiro Genilo. Published in Higher Education Evaluation and Development. Published by Emerald Publishing Limited. This article is published under the Creative Commons Attribution (CC BY 4.0) licence. Anyone may reproduce, distribute, translate and create derivative works of this article (for both commercial and non-commercial purposes), subject to full attribution to the original publication and authors. The full terms of this licence may be seen at http://creativecommons.org/licences/by/4.0/ legalcode 
HEED

16,2

IQACs in the country to help implement the directive. It should be noted that the paper did not intend to measure the effectiveness of IQAC interventions. It did not also attempt to measure the success of online teaching and learning strategies of various universities. However, it showcased the some of the practices and activities by the IQAC as it supported the UGC's concern on quality online learning.

\subsection{Pandemic situation}

The coronavirus disease (COVID-19) is an infectious ailment caused by a newly discovered coronavirus. According to the World Health Organization (WHO), most people infected with the COVID-19 virus will experience mild to moderate respiratory illness and recover without requiring special treatment. The elderly and those with underlying medical problems, on the other hand, are more likely to develop serious illnesses. As reported in the COVID-19 Dashboard of John Hopkins University, as of July 13, 2021, there were more than 187 million cases worldwide and more than 4 million deaths. The most affected countries included the USA, India, Brazil, Russia and France. In Bangladesh, there were 1,048,155 cases and 16,842 deaths as of this writing.

The Institute of Epidemiology, Disease Control and Research (IEDCR) confirmed the country's first three COVID-19 cases on March 8, 2020. Two of the infected individuals traveled from Italy, while the third person is a family member of one of the travelers. From then on, the number of positive cases gradually increased. In an effort to contain the spread of the virus, the Bangladesh government declared a general holiday on March 27. This has been extended several times over the course of the year. Given its demographic and health statistics, special measures needed to be undertaken as the country would be vulnerable to a pandemic. Based on the World Fact Book (2020), the country had an estimated population of more than 162 million with a median age of 27.9 years. It had a total dependency ratio of 47 (youth dependency ratio at 39.3 and elderly dependency ratio at 7.7).

Its health statistics were far from ideal for combating COVID-19 given that health expenditure was reported to be only $2.3 \%$ (2017) of gross domestic product (GDP). Physician density was 0.54 per 1,000 population and hospital bed density was 0.8 per 1,000 population. It should be noted that a great majority of the population $(61.8 \%)$ lived in the rural areas. The biggest city is its capital Dhaka with a population of over 21 million.

\subsection{Reponses from the education ministry}

To restrain the pandemic, the Ministry of Education on March 16, 2020, issued a directive ordering all education institutions to close. The decree was first extended on March 31, 2020, and has been extended multiple times since. To reinforce the Ministry's order, the UGC declared on March 23 that all universities introduce online education to run academic activities. Given this, universities throughout the country began preparations to shift to full online education so as not to disrupt the current academic year. On April 30, the Education Ministry urged universities to continue academic activities online, including exams and admissions. One month after, on June 1, the Ministry started easing restrictions first by allowing schools to re-open their administrative offices albeit classes were still conducted online. On October 18, universities were allowed to hold admission tests and on November 3, final term private university students were permitted to take in-person practical classes and exams.

The UGC reported that in 2017, there were 3.2 million students enrolled at the tertiary level; projecting the figure to reach 4.6 million over the next decade. Of the total number of students enrolled, Mannan (2017) mentioned that the theology-based Islamic University (Fazil and Kamil Madrasa) accounted for $8.2 \%$ and the National University System had $72 \%$ of the total tertiary student population. A madrasa is a college for Islamic education. The 
remaining $19.8 \%$ were registered in the 32 public and 84 private universities. According to Monem and Baniamin (2010), there are five types of higher education systems available in the country, which may be provided by the State as well as private and religious institutions. These are: (1) General Education; (2) Science and Technology and Engineering Education; (3) Medical Education; (4) Agricultural Education and (5) Distance Education. In addition, the higher education sector provides vocational and Madrasa education.

The types of higher education systems have different characteristics depending on its ownership structure. For example, the Online Open Academy (2020) explained that public universities are funded by the State, have large class sizes, lower tuition fees and have extended academic programs. As opposed, private universities have higher tuition fees, limited academic programs, small class sizes and are privately funded (nonprofit). This was shown in the Table 1.

In this situation, private universities may have an advantage in terms of shifting to full online learning as compared with their public counterparts given smaller class sizes, more affluent students and limited academic programs. Although public universities are funded, they may find it more difficult to transition given larger class sizes and less affluent students. The World Fact Book estimated in 2019 that the government only spent 1.3\% of GDP for education, which may not be enough to fully fund the said shift.

\subsection{Shift to full online learning}

There were two main concerns vis-à-vis the shift to full online learning in the country. The first had to do with the information technology (IT) infrastructure and the second was about ensuring the quality of full online education. Regarding the first, The Business Standard on June 22, 2020, placed forwards issues relating to the digital divide. It mentioned that although $87 \%$ of public university students have smart phones, many of them cannot afford to buy mobile data. In addition, Bangladesh had the costliest mobile data among South Asian nations. Only a few public universities were in a position to provide their students with devices and funds to buy Internet packages.

In addition, there was poor mobile Internet connection in hilly and char areas as well as in islands. Chars can be described as tracts of land surrounded by the waters of an ocean, sea, lake or stream; it usually means any accretion in a river course or estuary.

Due to the inadequate IT infrastructure and other issues, as shown in Table 2, 77\% of university students surveyed did not prefer online classes. Only $55 \%$ had devices to attend online classes; only $45 \%$ had Internet access. A high $87 \%$ did not believe that online assessments were feasible. Around 2,038 university students participated in the BioTed survey conducted on May 9-11, 2020. Around $66 \%$ of respondents were located in urban areas, while $34 \%$ in rural areas. Around $41 \%$ of respondents studied in private universities,

\begin{tabular}{lll}
\hline Attributes & Public universities & Private universities \\
\hline Funding source & State & Private (nonprofit organizations) \\
Tuition fee amount & Relatively lower & Relatively higher \\
Campus size & Relatively large & Relatively small \\
Class size & Relatively large & Relatively small \\
Admission & Highly competitive & Less competitive \\
Hostel facilities & Numerous & Limited \\
Research facilities & Numerous & Limited \\
Academic programs & Extensive & Limited \\
Cocurricular activities & Extensive & Limited
\end{tabular}

Source(s): Onlineopenacademy.com (December 2020)

Table 1. Main attributes of public and private universities in Bangladesh 
HEED

16,2

\section{2}

Table 2.

Students' stance relating to online learning while $59 \%$ in public universities. Amid these issues, the government undertook the following initiatives:

(1) March 27: Bangladesh Research and Education Network (BdREN) obtained a corporate license for Zoom; offering it free of cost to all universities.

(2) July 6: Mobile phone operators urged to provide low-cost or free Internet to students. Teletalk consented to provide free Internet on August 28.

(3) November 13: Grameenphone agrees to provide low-cost Internet package to students.

Regarding the second concern, which was about the quality of online learning, the UGC tried to track the shift toward online education using ten criteria in measuring quality education as shown in the table below.

Under a World Bank project called Higher Education Quality Enhancement Project (HEQEP), conducted from 2016 to 2018, the UGC required most universities to establish a IQAC. The main role of the IQAC was to establish a quality culture at the university, which included improving the aspects of governance and leadership; educational innovations; student support and progression; infrastructure and learning resources; research, consultancies and extension; teaching, learning and assessments and formulating outcome-based curricula. To evaluate the success of this quality culture, the UGC developed the said criteria shown in Table 3. The IQAC was tasked to guide each program offering entity in completing a self-assessment report, which illustrated how it complied with UGC criteria and standards. The self-assessment report was later validated through an external peer review - composed of three experts on quality assurance and/or the academic discipline. It should be noted that the UGC has conducted several trainings among the IQAC directors and additional directors to prepare them for these tasks. Most notable was the twoweek workshop on Professional Development Program on Quality Assurance in Higher

\section{Stance}

Percentage answering yes

Percentage answering no

Preference for online classes

Feasibility of online assessments

Availability of devices for online learning

Access to internet for attending online class

Source(s): BioTed survey (May 2020)

$\begin{array}{ll}23 & 77 \\ 13 & 87 \\ 55 & 45 \\ 45 & 55\end{array}$

77

87

45
55

\begin{tabular}{ll}
\hline No & Criteria \\
\hline 1 & Governance \\
2 & Curriculum design and review \\
3 & Physical facilities \\
4 & Students: Admission, progress and achievements \\
5 & Teaching and learning \\
6 & Assessment of student performance \\
7 & Student support services \\
8 & Staff \\
9 & Research and extension \\
10 & Process management for continual improvement
\end{tabular}

$\begin{array}{ll}\text { Table } 3 . & 9 \\ \text { UGC quality education } & 10\end{array}$ criteria

Source(s): University Grants Commission (2016) 
Education back in 2016 with batches of IQAC officials training in Thailand, Sri Lanka, India, Malaysia and the Philippines.

Under the HEQEP, the UGC established a quality assurance unit (QAU), which served as its direct link with each university's IQAC. Through this arrangement, the UGC has relied on the IQAC to help implement directives and monitor activities that deal with quality education. In February 2020, for example, it issued a memo requiring all universities to shift toward outcome-based curricula. Then, in January 2021, it announced the approval of the Bangladesh National Qualifications Framework (BNQF). As it expects the IQAC to assist in ensuring compliance to both directives, the UGC and the Bangladesh Accreditation Council (BAC) requested IQAC directors and additional director to attend a two-day workshop in June 2021 regarding the $\mathrm{BNQF}$ and the new accreditation criteria and standards. During the pandemic period, the UGC was concerned with the quality of online teaching. To monitor these activities, it communicated with the IQAC of the various universities in order to gain an understanding on what is happening on the ground.

Under this backdrop, the paper investigates the roles played by various IQACs in the country in supporting the UGC's concern vis-à-vis quality online education during the pandemic period. Given that classes are held in the virtual space, the paper focused on online teaching, learning and assessment, including the online platform utilized. It did not dwell on cocurricular and extracurricular activities although this may have been mentioned in passing.

\subsection{Research objective}

The research objective was to describe the roles played by the various IQACs in Bangladesh in supporting the UGC's concern for quality online learning during the pandemic. To do this, the paper utilized (as a framework) the five pillars of quality online education - learning effectiveness, student satisfaction, teacher satisfaction, scale and access.

\section{Study framework}

The paper used for its study framework the Sloan Consortium's Five Pillars of Quality Online Education. Lorenzo and Moore (2002, p. 3) explained that "online learners and instructors work outside any physical classroom (from their home, workplace or wherever there is a computer with an Internet connection) and interact with each other through electronic communications, such as e-mail and threaded online discussions. They also have access to electronic text (or print-based text), as well as multimedia learning resources - all part of a sophisticated virtual learning environment." In light of this, Lorenzo and Moore (2002, p. 3) contextualized the five pillars as a "framework for measuring and improving an online program within any institution." Enumerated, the five pillars included: (1) learning effectiveness; (2) faculty satisfaction; (3) student satisfaction; (4) scale and (5) access. The said five pillars were discussed in greater detail below, showing how they relate to quality online education, which was the concern of the UGC during the pandemic period.

(1) Pillar 1: Learning effectiveness pertains to instructors and course developers taking advantage of the uniqueness of the online learning environment in order to provide learning experiences representative of the institution's quality of education. One key feature of learning effectiveness is the extent of online interactions between students and teachers.

(2) Pillar 2: Student satisfaction refers to the satisfaction of the learners regarding their courses and their teachers. This may involve student surveys, group interviews and personal interviews regarding various aspects such as classroom management, course content, course delivery, learning resources and IT support. 
HEED

16,2

\section{4}

\section{Methodology}

The paper was qualitative and descriptive. Data were gathered from IQAC reports presented in two meetings - the first initiated by North South University on August 22, 2020, and the second organized by UGC on September 3, 2020. The number of IQAC reports was presented in Table 4.

Aside from the reports, newspaper articles on various aspects of the five pillars were examined and analyzed using the basic tenets of qualitative analysis.

\section{Results and discussion}

The results and discussion are organized based on the five pillars of quality online education - learning effectiveness, student satisfaction, faculty satisfaction, scale and access.

\subsection{Learning effectiveness}

Even before the pandemic, a few private and public universities have explored blended learning, which utilizes a mix of in-person and online class sessions. University administrators deemed blended learning as essential given a variety of reasons such as political turmoil (nationwide strikes and protest actions) and environmental issues (flooding and fire) that disrupt academic activities. At the University of Liberal Arts Bangladesh (ULAB), for example, authorities floated the idea of using Moodle (a free and open-source learning platform used for blended learning, distance education, flipped classroom and other e-learning projects worldwide) as early as the Spring Semester 2014. After obtaining approval from the Syndicate in February 2015, it official adopted the Moodle Learning Management System. Independent University Bangladesh (IUB) and American International University Bangladesh (AIUB) have entered into an agreement with Microsoft in 2018 for the use of Microsoft Teams - a communication platform that offers chat, video conferencing, file

Table 4. Meetings of IQACs in Bangladesh

\begin{tabular}{lcc}
\hline Details & Meeting 1 & Meeting 2 \\
\hline Date & August 22, 2020 & September 3, 2020 \\
Initiator & North South University & University Grants Commission \\
Total number of IQACs reporting & 7 & 19 \\
Number of IQACs from private universities & 6 & 7 \\
Number of IQACs from public universities & 1 & 13 \\
\hline
\end{tabular}


storage and application integration. IUB and ULAB have also formulated strategic directions vis-à-vis online education. IUB established its Institute for the Development of Online Learning while ULAB formed an Online Education Study Group that recommended measures regarding online teaching and learning at the university in 2018.

In light of this, when the UGC gave the directive, these universities did not find it difficult to shift to full online learning. The other universities, which did not have experience with blended learning, endured a greater struggle with the transition. Be this as it may, all universities needed to build or strengthen their online community, explore interactive online platforms and formulate academic policies addressing the said shift. The various IQACs played an important role in this regard. In building or strengthening the online community, the BioTed survey (presented earlier in section 1.3) revealed that most students did not prefer online classes and did not find online assessments feasible. Hence, the IQACs needed to persuade students and faculty alike to trust online education through workshops, posters, video productions, e-mail campaigns and other communication means. They were aware that online learning would not be effective if these groups did not buy into the system.

Moreover, the IQACs needed to establish learning guidelines regarding student and faculty behavior in an online setting. For example, the IQACs informed students that they should treat online classes similar to traditional classes. They need to come and leave classes at the designated times, select a safe and calm place to attend classes, read assignments ahead of time and ensure their active class participation. These guidelines delineated other measures to obtain the proper mindset and preparedness of learners in an online environment. To enhance student-teacher online interactions, IQACs recommended various digital apps such as Zoom, Google Meet and Google Hangouts for video conferencing, WhatsApp and Facebook Messenger for speedy communication with students and Google Docs, Facebook Groups and e-mails for document sharing. Aside from these, some IQACs explored other digital platforms to facilitate classroom collaboration such as Mentimeter, ThinkBoard and Virtual White Boards.

IQACs likewise facilitated broad consultations to formulate new academic policies on class attendance (whether to check or not), online assessment (assessment methods and question types), plagiarism checkers (how to contain copy and paste tendencies), virtual laboratory sessions (addressing the practical aspects of learning) and grade equivalency determination (give a grade or pass and fail mark). These policies were recommended to the universities' Academic Council for approval. For example, the academic council of the Bangladesh University of Engineering and Technology (BUET) agreed to have a no grade term (where students will not be given a numeric final grade) during the pandemic period. In general, university authorities encouraged flexibility among faculty - bearing in mind the mental and emotional state; Internet access problems and power disruptions and the needed adjustment to an online setting of learners. University authorities also motivated faculty to give assignments, written take home exams and viva voce (oral) exams in lieu of synchronous online written examinations. They had to think of online teaching and assessment strategies given the levels of Internet accessibility of its students.

\subsection{Student satisfaction}

University students were doubtful regarding the feasibility of full online learning at the initial stage of the school lockdown. As indicated in the BioTed Survey, most of the students did not prefer online classes and did not find feasible online assessments. Given this situation, some private universities (with the help of IQACs) conducted baseline surveys to determine the situation of students with regard to their mental and financial status as well as their Internet access. From the survey results, university authorities devised measures to address mental health concerns such as establishing counseling hotlines, conducting socialization activities 
HEED

16,2

and developing open communication systems. The responses of universities vis-à-vis financial status was discussed in Section 4.4, while Internet access will be discussed in Section 4.5.

To ensure student satisfaction, the UGC requested the various universities to monitor the conduct of online classes, including submitting a report on student attendance. At the top private universities, student attendance was very promising with North South University (NSU) even reporting an average attendance of $93 \%$. Online classes and exams were likewise conducted regularly. ULAB, for example, submitted on April 10, 2020, that $99.6 \%$ of online exams and $94 \%$ of online classes were held. Several public universities, on the other hand, explained that students found it difficult to attend online classes given Internet accessibility and affordability issues. They then requested the UGC to help address the situation. The details of UGC response will be discussed in Section 4.5.

Moreover, the UGC expected universities to continue with the student evaluation of courses and faculty members, which IQACs initially implemented during the HEQEP project. Course evaluation included the parameters of (1) course content and organization; (2) learning environment and teaching method; (3) student contribution; (4) teacher contribution and (5) learning resources. Faculty evaluation consisted of the following indicators: (1) subject matter knowledge; (2) presentation and class management skills; (3) assessment of learning; (4) efforts in developing students and (5) professional behavior. For universities to continue with course and faculty evaluations, they needed to establish online data collection methods. Moreover, they needed to instruct students regarding how to enter data using the digital system. There were differing successes in this regard. A few universities already had online evaluation systems and some were able to move toward this during the pandemic period. However, many universities found it difficult to switch from their course and faculty evaluation system.

Aside from these, under the HEQEP project, the UGC mandated universities to gather feedback from graduating students regarding the aspects of governance, teaching and learning, assessment, facilities and process management. Again, not all universities were able to continue with their graduate exit surveys as data collection needed to shift online as well.

From the universities that were able to conduct course and faculty evaluations as well as graduate exit surveys, there was little difference in the scores before and during the pandemic. Apparently, these IQACs reported that student satisfaction with their courses and faculty was retained given that they had:

(1) personalized interactions with the faculty;

(2) longer interactions with faculty and fellow students;

(3) experienced flexibility in attendance, assignments and assessment methods;

(4) continued access to online library resources and

(5) open line of communication with academic administrators.

In a few private universities, the IQACs assisted in conducting a follow-up student satisfaction survey on online education. This time, the survey was conducted a year after the school lockdown and shift toward online learning. One private university, for example, conducted a survey with 272 respondents regarding their perceptions about the online education experience in the areas of technology and accessibility; structure and interface; teaching and learning; socialization with and among students; student learning assessment and future experience with online learning. As illustrated in Table 5, overall student perception was satisfactory with a mean rating of 3.47 ( 1 being the lowest and 5 being the highest). Students gave the best response to technology and accessibility with a mean rating 
of 3.71 as they found instructors to be technologically updated and the online platform to be accessible and adequate for learning purposes. They gave the lowest responses to student learning assessment (3.37) and future experience with online learning (3.28). Students found online education to be wanting in terms of evaluating higher order thinking and assessing student work promptly and properly. Regarding their future experience, they mentioned dealing with Zoom fatigue as the main reason for the score.

Priyo and Hazra (2021), after surveying 204 private university students, found out that $58 \%$ of respondents preferred recorded lectures to live/real-time online classes. The respondents reasoned that they liked the flexibility to watch at their own time (74\%), can go over the recordings as many times as needed $(71 \%)$, liked the act of downloading the lecture (50\%), can ask relevant questions to the teacher at their own time ( $46 \%)$ and can get an equal chance of asking questions even with slower Internet connections (45\%). Respondents who disliked live/real-time classes complained connectivity problems (84\%), inaccessibility of materials presented online (51\%), lack of time flexibility ( $47 \%$ ), undue advantage of students with high-speed Internet (43\%) and stress in ensuring attendance during live sessions $(40 \%)$. These surveys will be useful in influencing future university academic policies on online teaching and learning.

\subsection{Faculty satisfaction}

Several capacity building activities were conducted during the pandemic period - for all universities, between universities and within a university. For all universities, the UGC and the Foundation for Teaching and Research (FLTR) conducted trainings for administrators and teachers of various universities. The UGC held a workshop from November 29 to December 1, 2020, regarding improving student engagement in online classes. The FLTR, meanwhile, launched a six-day training course called "Certificate on e-Learning and Teaching." Participants attended the training during weekends in November to December 2020. The FLTR is a platform to improve teacher capacity, established by nine vice chancellors of reputed private universities. FLTR is currently chaired by the vice chancellor of Green University Bangladesh.

Given the strong network between universities, school authorities (including IQAC officials) conducted talks and trainings among each other. For example, City University's IQAC held a webinar on virtual class on June 30, 2020; Dhaka International University (DIU) IQAC on Internet connectivity, collaboration and virtual teaching-learning on August 24, 2020; and East West University IQAC on outcome-based education on November 13-14, 2020. City University's IQAC conducted another webinar on e-Learning Systems on June 23, 2020. Most IQACs reported undertaking a host of workshops either by itself or in tandem with their Center of Excellence in Teaching and Learning. They conducted workshops on the various e-learning and video conferencing platforms and applications such as Google Classroom, Zoom and Moodle. They likewise oriented the faculty regarding e-Learning pedagogies and

\begin{tabular}{lrr}
\hline Parameters & Mean rating \\
\hline Technology and accessibility & 3.71 \\
Structure and interface & 3.56 & 3.47 \\
Teaching and learning & 3.46 & Table 5. \\
Socialization with and among students & 3.37 & ULAB student \\
Student learning assessment & 3.28 & education after a year's \\
Future experience with online learning & 3.47 & experience \\
Overall & & \\
\hline
\end{tabular}


HEED

16,2

assessments, including e-classroom management and appropriate student behaviors in eclassrooms. Additionally, a few universities established Facebook Groups among faculty members to serve as a platform where teachers can exchange notes regarding online teaching, learning and assessment.

To ensure faculty satisfaction, some universities conducted a baseline survey among teachers regarding their physical wellness, psychological wellness, financial wellness, online class response and support needed to improve online class response. From the survey results, authorities instituted some policies to address their concerns. Moreover, quite a few universities were successful in continuing the Institutional Quality Assurance Survey (IQAS), which were initially conducted during the HEQEP project. The IQAS measures teacher satisfaction with various university parameters such as governance, curriculum, teaching and learning, assessment, facilities, research, extension, human resource management and process management.

\subsection{Scale}

The Bangladesh economy suffered a serious setback given the COVID-19 pandemic, which plummeted investment, external sector performance and employment. The World Bank projected the country's GDP to grow by only $1.6 \%$ in fiscal year 2019-2020 compared to $8.15 \%$ in the previous fiscal year. Moreover, the number of people living below the poverty line is expected to double by the end of 2020. In June 2020, the Prime Minister's Office Aspire to Innovate (A2I) Program reported that more than 2.5 million jobs were lost. The hardest hit sectors included tourism, transportation, garments, SMEs, informal sector, light engineering and construction.

The economic downturn was felt in the education sector - more with private rather than public universities. Since public universities are funded by the government and students pay only minimal fees, they have been left relatively unaffected by the economic crisis (except for the onset of online class sessions which require Internet access). In the private university sector, the situation was radically different. Although almost all private universities conducted online classes, they claimed to be facing a financial crunch given that:

(1) more than $20 \%$ of their students took a break from studying;

(2) many of those students who continued their studies could not afford to pay and

(3) new students could not be admitted due to the cancellation of government secondary school exams.

In light of this, several university teachers complained to the UGC that their salaries have been cut by 35-70\% in March 2020; salaries for April and May 2020 have been decreased as well. Moreover, teachers needed to allot BDT 4,000 (USD 50) per month for the purchase of mobile data in order to conduct online classes and develop new lesson plans. Stamford University Associate Professor Sheikh Nahid Neazy, in an opinion piece dated May 8, 2020, added that private universities lacked financial transparency and accountability. According to him, private university authorities are not transparent about their annual budgets and most of them do not submit proper annual audit reports to the UGC.

Based on their reports, the role of IQACs under this pillar were two-fold: (1) monitoring dropout rates and (2) conducting a survey to learn about the financial status of students and their families. With these information, private university authorities can devise financial policies to help students in these difficult times such as increasing tuition fee waivers and scholarships, instituting flexible tuition fee payment plans and cutting fees for services students would not receive during the school closure. It should be noted, however, that a few students in two private universities held protest actions demanding for more tuition fee 
waivers, reduction of tuition fees and mobile data allowances. Understandably, given the sudden shift, private universities have yet to determine cost effectiveness in online learning.

\subsection{Access}

Both students and university administrators played a part in gaining access to online learning. On the part of the learners, they needed to invest in a device and purchase mobile data for Internet access. On the part of universities, an e-learning platform should have been provided to their learners. Based on the BioTed survey, $55 \%$ of student respondents possessed a device, while $45 \%$ had Internet access. However, according to IQAC reports, the lack of a device and Internet access was felt more in public universities as compared to their private counterparts. For example, NSU mentioned that most of their students have smart phones and can afford to purchase mobile data. ULAB, after conducting a student survey, found out that $98 \%$ of their students have devices such as smart phones, desktops, tablets and laptops. In addition, $90 \%$ of their students have Internet access (albeit $62 \%$ of these have slow to moderate Internet speed). To address the issue, the UGC negotiated for free or cheap mobile data packages for students among the telecommunication service providers, particularly Teletalk and Grameenphone.

Regarding e-learning platforms, BdREN has provide all universities licensed access to the videoconferencing tool Zoom. This enabled the universities to engage in synchronous online sessions. However, for full online learning to be more effective, there is a need for asynchronous online sessions as well. Given this, some universities have either developed their own or adapted open-access online learning management systems. For example, Brac University and Daffodil International University (DIU) have developed their own learning management systems, which have the capacity for recording video lectures, checking attendance, facilitating class discussions and computing student performance. At the same time, these learning platforms enable students to share and collaborate with their fellow classmates and their teachers. ULAB, as opposed, has been utilizing since 2015 the openaccess Moodle learning management system, which among others facilitate asynchronous class discussions. However, to complement Moodle, ULAB authorities encouraged faculty to utilize other online platforms to facilitate teacher-student interactions. The goal of this directive was to prioritize the delivery of the course content rather than focus on the platform used.

As a whole, universities in the country still struggle with access to online learning whether it involved students having their own devices and Internet access or whether it entailed school authorities investing in their own online learning management systems.

\section{Summary and conclusion}

When the pandemic hit the country, universities were forced to shift to full online learning. In so doing, they faced a myriad of challenges to ensure quality education in the digital platform in terms of learning effectiveness, student satisfaction, teacher satisfaction, scale and access. The government managed some of the problems relating to IT infrastructure (offering the licensed use of Zoom and negotiating for free or low Internet cost for students). It had likewise monitored the conduct of online class sessions as well as provide trainings on virtual classes. Nevertheless, the UGC relied on IQACs to play a supporting role in ensuring quality in full online learning. IQACs responded in the following manner:

(1) Feedback mechanisms. IQACs helped conduct student surveys, faculty surveys and follow-up surveys. Many of them likewise continued with teacher and course evaluations and checked faculty attendance in the online platform. responses to the pandemic 
HEED

16,2

\section{0}

(2) Capacity building. IQACs conducted several trainings to support the shift to full online learning. It discussed the various online platforms and online teaching pedagogies to the faculty. Given the relationship between IQACs, the trainings and workshops were conducted between universities as well.

(3) Draft academic recommendations. IQACs drafted academic policies and guidelines relating to student assessments, student online behavior and online teaching management. The said policies and guidelines were taken by the academic councils of the various universities.

(4) Online learning platforms. IQACs made recommendation regarding online learning platforms for consideration of the university management.

(5) Monitoring attendance. IQACs submitted to UGC the student attendance in the various courses, especially during the start of the school lockdown. In so doing, IQACs were able to help in identifying drop-out rates in their respective universities.

Universities in Bangladesh have simply started their journey toward ensuring quality in online education. A lot more lessons are expected to be learned in the future. But, rest assured, the IQACs under the guidance of the UGC, will be there to support and ensure quality education - whether online or in-person.

\section{References}

Lorenzo, G. and Moore, J. (2002), "Five pillars of quality online education", Sloan Consortium Report to the Nation, November, available at: https:/www.immagic.com/eLibrary/ARCHIVES/ GENERAL/SLOANCUS/S021106L.pdf.

Mannan, A. (2017), “Achieving our higher education targets”, The Daily Star, 25 February, available at: https://www.thedailystar.net/education-employment/achieving-our-higher-education-targets1366513.

Monem, M. and Baniamin, H.M. (2010), "Higher education in Bangladesh: status, issues and prospects", Pakistan Journal of Social Sciences, Vol. 30 No. 2, available at: file:///D:/Downloads/ Higher_Education_in_Bangladesh_Status_Issues_and_P.pdf.

Neazy, S.N. (2020), "Private universities cut faculty salaries", The Daily Sun, 8 May, available at: https:// www.daily-sun.com/printversion/details/480691/Private-Universities-Cut-Faculty-Salaries.

Online Open Academy (2020), "Public university vs. private university", 28 December, available at: http://onlineopenacademy.com/public-university-vs-private-university-paragraph/.

Priyo, A.K.K. and Hazra, U. (2021), "Digital divide in online class during Covid-19 pandemic", The Financial Express, 19 July, available at: https:/today.thefinancialexpress.com.bd/views-opinion/ digital-divide-in-online-class-during-covid-19-pandemic-1626616783.

University Grants Commission (2016), Institutional Quality Assurance Cell Operations Manual, 2nd ed., University Grants Commission, available at: http://www.qau.gov.bd/system/files/publication/ SAMANIAL_20162ndeditionFINAL_0.pdf.

\section{Further reading}

Ahmed, A.U., Zaman, A-U. and Zakir Khan, Z. (2020), Post COVID Jobs and Skills in Bangladesh, Future of Work Lab, Aspire to Innovate (A2I) Programme, Prime Minister's Office.

Center for Systems Science and Engineering, John Hopkins University (2020), “COVID-19 dashboard”, 27 December, available at: https://gisanddata.maps.arcgis.com/apps/opsdashboard/index. html\#/bda7594740fd40299423467b48e9ecf6.

Central Intelligence Agency (2020), "The world fact book”, 27 December, available at: https://www.cia. gov/library/publications/the-world-factbook/geos/bg.html. 
Costly data, poor connection key challenges for online classes in public universities (2020), "The business standard", 22 June, available at: https://tbsnews.net/bangladesh/education/costly-datapoor-connection-key-challenges-online-classes-public-universities.

Garda.com (2020), "Bangladesh: first cases confirmed on March 8", 8 March, available at: https://www. garda.com/crisis24/news-alerts/320606/bangladesh-first-cases-of-covid-19-confirmed-march-8.

Hegarty, B. (2015), “Attributes of open pedagogy for using open educational resources", available at: https://www.researchgate.net/publication/281286900_Attributes_of_Open_Pedagogy_A_ Model_for_Using_Open_Educational_Resources.

Kamol, E. (2020), "Private university teachers allege job cuts, non-payment", New Age, 14 July, available at: https://www.newagebd.net/article/111126/private-university-teachers-allege-jobcuts-non-payment.

Online Classes for University Students in Bangladesh during the COVID-19 Pandemic - Is It Feasible (2020), “The business standard", 1 June, available at: https://tbsnews.net/thoughts/onlineclasses-university-students-bangladesh-during-covid-19-pandemic-it-feasible-87454.

Online Classes: Increasing the Education Divide (2020), "Star forum", The Daily Star, 17 July, available at: https://www.thedailystar.net/opinion/news/online-classes-increasing-the-education-divide1931409.

Salim, R. and Kabir, M. (2020), "The shadow of COVID-19 lingers over Bangladesh's economy”, East Asia Forum, 7 November, available at: https:/www.eastasiaforum.org/2020/11/07/the-shadowof-covid-19-lingers-over-bangladeshs-economy/.

TimeandDate.com. (2020), "Public holiday observances in Bangladesh", 27 December, available at: https://www.timeanddate.com/holidays/bangladesh/public-holiday-covid-19.

University of California (2020), "Five pillars of quality online education", 28 December, available at: https://cole2.uconline.edu/courses/209413/pages/five-pillars-of-quality-online-education.

World Health Organization (WHO) (2020), “Coronavirus”, 27 December, available at: https://www.who. int/health-topics/coronavirus\#tab=tab_1.

\section{Corresponding author}

Jude William Ramiro Genilo can be contacted at: jude.genilo@ulab.edu.bd

For instructions on how to order reprints of this article, please visit our website:

www.emeraldgrouppublishing.com/licensing/reprints.htm

Or contact us for further details: permissions@emeraldinsight.com 